\title{
Muhasebe Meslek Mensuplarının Hizmet Kalitesi ile Müşteri Memnuniyeti ve Ağızdan Ağıza İletişim İlişkisi
}

\author{
Erkan DENDEŞ1,2, Ece AKSU ARMAĞAN³ ${ }^{3}$ Aslı ERINCİK DENDEŞ ${ }^{4}$
}

Özet

Son yıllarda hizmet işletmelerinin sayısının artması ve hizmetlerin soyut özellik taşıması, sunulan hizmetin kalitesinin ölçümüne yönelik çalışmaların artmasına neden olmuştur. Literatürde hizmet kalitesinin ölçümüne yönelik olarak farklı ölçüm araçları geliştirilmiştir. Araştırmanın amacı, SERVQUAL ölçeği kullanılarak Aydın ilinde faaliyette bulunan işletmelerin muhasebe bürolarından aldıkları hizmetin kalitesi ile müşteri memnuniyeti arasındaki ilişkiyi ve ağızdan ağıza iletişime etkisini ortaya koymaktır. Yapılan değerlendirme sonucunda Aydın ilinde faaliyette bulunan ve muhasebe bürolarından hizmet alan işletmeler, sunulan hizmet kalitesini sırasıyla güvenilirlik, empati ve fiziksel özellikler boyutlarında algıladıkları, müşteri memnuniyetini empati, güvenilirlik ve fiziksel özelliklerin olumlu yönde arttırdığı ve müşteri memnuniyetinin de ağızdan ağıza iletişimi olumlu ve pozitif yönde etkilediği tespit edilmiştir.
Anahtar Kelimeler

Hizmet

Hizmet Kalitesi

SERVQUAL

Muhasebe Meslek Mensupları Ağızdan Ağıza İletişim

Makale Hakkında

Geliş Tarihi: 08.04.2018

Kabul Tarihi: 26.03.2021

Doi: 10.18026/cbayarsos.901665

\section{Relationship between Service Quality of Accounting Profession Members and Customer Satisfaction and Word of Mouth}

\section{Abstract}

In recent years, the increase in the number of service businesses and the intangible feature of services have led to increased efforts to measure the quality of the provided service. Different measurement tools have been developed in the literature to measure service quality. The purpose of the research is to demonstrate the relationship between the quality of service provided by the accounting offices of the companies operating in the city of Aydin using the SERVQUAL scale and customer satisfaction and the effect of Word-of-Mouth. As a result of the evaluations made, the firms operating in the city of Aydin and receiving service from the accounting departments have found that they perceive the service quality in terms of reliability, empathy and physical characteristics respectively, increase customer satisfaction in favor of empathy, reliability and physical characteristics and customer satisfaction in a positive direction.
Keywords

Service

Service Quality

SERVQUAL

Accounting Profession Members

Word-of-Mouth

About Article

Received: 08.04.2018

Accepted: 26.03.2021

Doi: 10.18026/cbayarsos.901665

\footnotetext{
1 İletişim Yazarı: edendes@adu.edu.tr

${ }^{2}$ Dr. Öğr. Gör., Aydın Adnan Menderes Üniversitesi / Karacasu Meslek Yüksekokulu Karacasu-Aydın ORCID numarası: 0000-0002-6685-9844

${ }^{3}$ Doç.. Dr. Aydın Adnan Menderes Üniversitesi / Nazilli İktisadi ve İdari Bilimler Fakültesi Nazilli-Aydın Doç. ORCID numarası: 0000-0001-5371$219 X$

4 Aydın Adnan Menderes Üniversitesi / Sosyal Bilimler Enstitüsü Yüksek Lisans Aydın ORCID numaras1: 0000-0001-7685-9848
} 


\section{Giriş}

1990'lı yıllardan itibaren küreselleşme kavramının hayatımıza girmesi ile birlikte dünyada çok büyük değişimler meydana gelmiştir. Özellikle, teknolojide yaşanan gelişmelere paralel olarak tüketici davranışlarında meydana gelen değişimler sektörler içerisindeki hem hizmet sektörünün payının hem de rekabetin artmasına neden olmuştur. Hizmet sektörünün bir parçası olan muhasebecilik mesleğinin de yaşanan bu yoğun rekabet ortamından etkilendiği söylenebilir.

Muhasebe ve muhasebecilik mesleği, gelecekle ilgili planların oluşturulmasında işletmelere geçmişe yönelik doğru ve güvenilir bilgiler sağlayarak kararların doğru ve etkin bir şekilde alınmasına yardımcı olur (Ertuğrul ve Özdemir, 2014). Çünkü muhasebe mesleğinin çıkış noktasını, insanların sahip olduğu ekonomik değerlerin kontrol edilmesi ve bu değerlerin faydalarının arttırılması düşüncesi oluşturmaktadır (Albez ve Bilici, 2012).

Türkiye'de muhasebecilik mesleği, 3568 Sayılı Serbest Muhasebeci Mali Müşavirlik ve Yeminli Mali Müşavirlik Kanunu ile düzenlenmiş olup ilgili kanun 13.06.1989 tarih 20194 sayılı Resmi Gazetede yayınlanarak yürürlüğe girmiştir. Kanunla daha önceden muhasebecilik mesleği ile uğraşan herkese serbest muhasebeci unvanı verilmiş olup muhasebe meslek elemanları Serbest Muhasebeci, Serbest Muhasebeci Mali Müşavir ve Yeminli Mali Müşavir olarak üç sınıfa ayrılarak mesleğin konusu ve çalışma alanı belirlenmiştir. Ancak, 26.07.2008 tarih ve 26948 sayılı Resmi Gazete' de yayınlanan 5786 sayılı Kanun ile 3568 Sayılı Kanunda değişiklik yapılarak serbest muhasebeci unvanı kaldırılarak meslek mensupları Serbest Muhasebeci Mali Müşavir ve Yeminli Mali Müşavir olarak iki kategoride sınıflandırılmıştır.

Müşterilerin beklentilerini karşılayacak hizmeti vermek tüm işletmelerin olduğu gibi muhasebe hizmeti sunan işletmelerin de ortak hedeflerinden biridir. Muhasebeci ile müşterileri arasındaki ilişkide, müşteriler muhasebecilerden muhasebe ve vergi işlemlerinde dikkat, titizlik, bilgilendirme, izleme vb. ihtiyacı ve duyarlılığını ve muhasebe ve vergi işlemleriyle sınırlı olmayan ek hizmetler ve sunumlar beklemektedirler (Yükselen, 2013). Yapılan bir çalışmada muhasebecilerin işletmelerin beklentilerini karşılama düzeyinin düşük olduğu anlaşılmaktadır. Muhasebe hizmeti sunan işletmeler müşteri memnuniyetini daha da ileriye taşıma gayreti içindedirler. Uzun süreli müşteri memnuniyetini ve rekabet avantajını elde etmenin yollarından en önemlisi şüphesiz tüketici beklentisini karşılayan ve aşan hizmet kalitesidir.

Muhasebe meslek mensuplarının 5786 Sayılı Kanun kapsamında reklam yapmasının yasak olması ve ücretlendirmenin tarifeye bağlanması gibi nedenler, muhasebe meslek mensubu tarafından sunulan hizmetin kalitesinin algılanması açısından kısıtlayıcı olarak görülebilir. $\mathrm{Bu}$ durumun doğal sonucu olarak muhasebe meslek mensubunca müşteri beklentilerinin somut taahhütlerle karşılanamaması mesleğin icrasında sözlü iletişimin önemini arttırır (Banar ve Ekergil, 2010). Başka bir ifadeyle diğer sektörler içinde yer alan firmaların müşteri bulma ve tutundurmaya yönelik yaptığı fiyat indirimleri, promosyon, reklam ve markalaşma gibi faaliyetler muhasebe meslek mensupları tarafından yapılamamaktadır. $\mathrm{Bu}$ nedenle meslek mensupları müşteriyi elde tutmak için hizmet farklılaştırması yoluyla müşterinin kendisini özel hissedeceği, güvene dayalı karşılıklı uzun süreli bir ilişki kurmak zorundadır. Bu da müşteriyi tanıma, anlama ve ona uygun çözümler üretmeyi zorunlu hale getirmektedir (Kaya ve Özdemir, 2014). Muhasebe hizmeti satın almak isteyen bir müşteri açısından tavsiyeler oldukça önemlidir. Çünkü muhasebe hizmeti satın alan müşteriler aldığ hizmetten duyduğu memnuniyeti olumlu referans olarak başkalarına aktarırlar. Bu nedenle, 
mevcut müşterilerin memnuniyeti ne kadar fazla olursa, ağızdan ağıza iletişimin etkisi o kadar fazla olacaktır (Eru ve Köroğlu, 2015).

$\mathrm{Bu}$ amaçla çalışmada, Aydın ilinde faaliyette bulunan işletmelerin muhasebe bürolarından satın aldıkları hizmetleri "kaliteli hizmet" olarak nasıl nitelendirdikleri, hizmet kalitesi ile müşteri memnuniyeti arasındaki ilişkinin SERVQUAL ölçeğinin beş boyutunun hangi boyut veya boyutlarından daha fazla etkilendiği ve müşteri memnuniyetinin ağızdan ağıza iletişim üzerinde etkili olup olmadığı araştırılmaktadır.

\section{Kavramsal Çerçeve}

\section{Hizmet, Hizmetin Özellikleri, Hizmet Kalitesi ve Ölçülmesi}

Hayatın her aşamasında karşılaşılan ve yararlanılan hizmetin literatürde birçok tanımının yapıldığ1 görülmektedir. Hizmet, İktisat Terimleri Sözlüğ̈̈'ne göre "gereksinimleri karşılama ve üretildiği anda tüketilme özelliklerine sahip her türlü etkinlik" olarak tanımlanırken, Ana Britannica'ya göre ise "ekonomide, elle tutulur maddi ürünler dışında her türlü yararlı çalışma ve etkinliğin üretildiği sektör" olarak tanımlanmıştır (Eleren ve Kılıç, 2007). Diğer yandan Amerikan Pazarlama Birliği'ne hizmet "bir malın satışına bağlı olmaksızın son tüketicilere ve işletmelere pazarlandığında istek ve ihtiyaç doygunluğu sağlayan ve bağımsız olarak tanımlanabilen eylemler" olarak ifade edilmiştir (Ersöz, Pınarbaşı, Türker ve Yüzükırmızı, 2009). Bir başka tanımlamaya göre ise "tüketici ihtiyaçlarının tatmin edilmesi amacıyla meydana getirilen maddi niteliği olmayan ürün; zaman, yer, biçim ve psikolojik yararlar sağlayan ekonomik faaliyet; tüketicilerin mülkiyetle ilişkisi olmaksızın satın aldıkları faydalar" şeklinde yapılmıştır (Devebakan, Koçdor, Musal ve Güner, 2003).

Hizmetlerin soyutluluk, ayrılmazlık, heterojenlik ve bozulabilirlik gibi bir takım karakteristik özellikleri vardır (Freeman ve Dart, 1993). Hizmetlerin soyutluluk özelliği göstermesi hizmetlerin nesnelerden ziyade performanslara dayalı olmasından kaynaklanır. Bu özelliği nedeniyle hizmetler satış öncesinde ölçülemez, sayımı yapılamaz ve test edilemez (Armstrong ve Smith, 1996). Ayrılmazlık özelliği hizmet üretiminin ve tüketiminin aynı anda gerçekleşmesini, heterojenlik özelliği hizmetin üreticiden üreticiye, tüketiciden tüketiciye ve yerden yere gün geçtikçe farklılık göstermesini ve bozulabilirlik özelliği ise hizmetlerin depolanamamasinı ifade eder (Ladhari, 2009).

Kalitenin anlaşılmaz ve belirsiz bir kavram olarak karşımıza çıkmasını nedeni genellikle "iyilik, lüks, parlaklık ya da ağırlık" gibi yanlış olan sıfatlar ile karıştırılmasından kaynaklanmaktadır (Parasuraman, Zeithaml ve Berry,1985). Literatüre bakıldığında kalitenin tanımına yönelik ilk çalışmaların fiziksel ürünlerin tanımlanmasına yönelik olması nedeniyle araştırmacılar kalite kavramına değişik bakış açıları ile yaklaşmışlardır (Koçoğlu ve Aksoy, 2012).

Kalite Feigenbaum'a göre "değer", Juran'a göre "kullanıma uygunluk" ve Crosby'e göre "şartlara uygunluk" olarak ifade edilmektedir (Reeves ve Bednar, 1994). Avrupa Kalite Kontrol Organizasyonu ise (EOQC) kaliteyi "belirli bir malın veya hizmetin, müşteri isteklerine uygunluk derecesi" şeklinde tanımlamıştır (Arlı, 2012).

Müşterilerle tatmin edici ilişkilerin kurulması ve sürdürülmesinin önkoşulu verilen hizmetin kalitesidir. Bu nedenle hizmet kalitesi ile müşteri memnuniyeti arasında önemli ve stratejik bir ilişki olduğu varsayılmaktadır (Lassar, Manolis ve Winsor, 2000). Dolayısıyla, hizmet kalitesi, bir firmanın rakiplerinden ayırt etmeye yönelik çabalarında kritik bir başarı faktörü olarak kabul edilmektedir (Ladhari, 2009). 
Hizmet kalitesi, sunulan hizmet seviyesinin müşterilerin beklentilerini ne derecede karşıladığının bir ölçüsüdür (Ghobadian, Speller ve Jones, 1994). Hizmet kalitesini Parasuraman, Zeithaml ve Berry (PZB) "bir tutum olarak tüketicinin beklenti seviyesi ile gerçek tecrübe arasındaki fark" (Ueltschy, Laroche, Eggert ve Bindl, 2007), Kasper ve arkadaşları "hizmetin, hizmet sürecinin ve hizmet organizasyonunun müşterinin beklentilerini tatmin etme derecesi" şeklinde tanımlamıştır (Wang, Lin ve Tseng, 2011).

Hizmetlerin soyut özelliğe sahip olması hizmet kalitesinin de soyut özelliğe sahip olmasına neden olduğundan hizmet kalitesi yerine "algılanan hizmet kalitesi" terimi literatürde daha yaygın olarak kullanılmaktadır (Devebakan, Koçdor, Musal ve Güner, 2003). Algılanan hizmet kalitesi, algılanan hizmetle beklenen hizmetin müşteri tarafından karşılaştırılmasının bir sonucu şeklinde tanımlanmaktadır (Bojanic, 1991). Diğer bir ifadeyle algılanan hizmet kalitesi müşterinin satın almadan önceki hizmet beklentisi ile satın aldıktan sonraki performans kıyaslamasının bir sonucu olup, müşteri beklentileri ile algılanan performans arasındaki farklılığın yönü ve derecesi olarak ifade edilir. Eğer algılanan hizmet kalitesi, beklenen hizmet kalitesinin altında gerçekleşirse, müşteriler işletme ve sunulan hizmete ilgilerini kaybederken, beklentileri karşılaması veya aşması durumunda ise o hizmeti satın almayı devam ederler (Arlı, 2012). Hizmet kalitesi literatüründe "beklentiler" müşterilerin hizmete ilişkin istek ya da arzuları olarak ifade edilir (Bulgan ve Gürdal, 2005).

Yapılan araştırmalar, müşterilerin kaliteyi tek boyutlu bir kavram olarak algılamadıklarını ileri sürmektedir (Ismail, Haron, Ibrahim ve Isa, 2006). Nitekim Gronroos hizmet kalitesini "teknik kalite, fonksiyonel kalite ve firma imajı" olarak üç boyutta, Lehtinen ve Lehtinen "fiziksel kalite, firma kalitesi ve etkileşim kalitesi" olarak üç boyutta, Sasser, Olsen ve Wyckoff "malzeme düzeyi, tesisler" ve personel" olarak üç boyutta, Jarmo Lethinen "süreç kalitesi ve çıktı kalitesi" olarak iki boyutta ve PZB "fiziksel özellikler, güvenilirlik, heveslilik, güven ve empati" olmak üzere 5 boyutta incelemişlerdir (Parasuraman, Zeithaml ve Berry, 1985; Ghobadian, Speller ve Jones, 1994; Pinho, Macedo ve Monteiro, 2007).

Literatürde, hizmet kalitesini ölçmek için geliştirilen başta SERVQUAL, SERVPERF, Toplam Kalite Endeksi Yöntemi, Kritik Olay Yöntemi, Hizmet (LINJEFLY) Barometresi, İstatistiksel Yöntemler, Benchmarking ve diğer yöntemler olmak üzere birçok alternatif model ve araç bulunmaktadır (Uzun, 2015). İşletmelerin sundukları hizmetlerin kalitesini geliştirebilmesi veya daha ileri bir seviyeye taşımaları ancak hizmet kalitesi açısından mevcut durumlarının tespitine ve eksikliklerinin belirlenmesine bağlıdır. Bu nedenle işletmeler açısından bakıldığından hizmet kalitesinin ölçülmesi hayati önem arz etmektedir.

Hizmet kalitesini ölçmek için en yaygın araç olarak kullanılan araç PZB'nin geliştirdiği SERVQUAL skalasıdır ve bu skala hizmet kalitesinin tüketici algısını ölçmek için çeşitli endüstrilere uygulandığında, yüksek güvenilirlik derecesine sahiptir (Chen, 2011). SERVQUAL ölçeği sırasıyla müşterilerin beklentilerini ve algılarını kaydeden iki benzer 22 maddelik bölüm kullanılarak hizmet kalitesinin beş boyutunu (fiziksel özellikler, güvenilirlik, heves, güven ve empati) ölçmek amacıyla tasarlanmıştır (Saxby, Ehlen ve Koski, 2004). SERVQUAL ölçeğinin hizmet kalitesi boyutları aşağıda belirtilmiştir (Devebakan ve Aksaraylı, 2003);

- Fiziksel Özellikler (Tangibles): İşletmenin fiziksel olanakları, araç-gereç ve personelin görünüşü.

- Güvenilirlik (Reliability): Taahhüt edilen hizmetin güvenilir ve doğru bir şekilde yerine getirebilmesi. 
- Heveslilik (Responsiveness): Şikayet ve müşteri ihtiyaçlarını hızlı bir şekilde yerine getirme isteği.

- Güven (Assurance): İşletme çalışanlarının bilgili, nazik olması ve müşterilerde güven duygusu yaratmasi.

- Empati (Empathy): Kendini müşteri yerine koyma ve müşterilerle kişisel olarak ilgilenilmesi.

Parasuraman ve arkadaşları tarafından önerilen ölçek, hizmet organizasyonunun kalite algısını etkileyen belirgin faaliyetlerini göstermeye çalışmaktadır. Dahası ölçek, bu faaliyetler arasındaki etkileşimi gösterir ve memnuniyet verici bir hizmet kalitesi seviyesine ulaşma ile ilgili hizmet organizasyonunun temel faaliyetleri arasındaki bağlantıları tanımlar. Bağlantılar, boşluklar veya tutarsızlıklar olarak tanımlanır: boşluk, tatmin edici bir hizmet kalitesi seviyesine ulaşmada önemli bir engel oluşturur. Ölçek düzgün bir şekilde kullanıldığında, yönetimin sistematik olarak hizmet kalitesi eksikliklerini tespit etmesini sağlar. Başka bir deyişle, hizmet kalitesini etkileyen çeşitli değişkenler arasındaki boşlukların belirlenmesini kolaylaştırır. Ayrıca, ilgili hizmet kalitesi faktörlerini müşterinin bakış açısından tanımlayarak yönetime yardımcı olma potansiyeli vardır.

Cronin ve Taylor, hizmet kalitesinin sadece algılanan hizmet kullanılarak ölçülmesi gerektiğini savunarak PZB'nin “boşluk teorisi”ne alternatif olarak Servperf ölçeğini geliştirmişlerdir (Güney ve Dizman, 2015).

Hizmet kalitesi, müşterilerin memnuniyetini ön planda tuttuğu için müşteri algılamasının kritik bir bileşenidir. Mükellefin aldığı hizmetin kalitesinin beklentileri düzeyinde veya üzerinde olduğunu görmesi, hizmet işletmesinin performansını olumlu değerlendirmesi sonucunu yaratır. Muhasebe ve mali müşavirlik hizmetinin kalitesini belirleyecek olan müşteridir (Koç, Şahin ve Özbek, 2014). Bu nedenle müşterinin ihtiyaç ve istekleri ile beklentilerini saptamak ve bunları en uygun şekilde karşılamak muhasebe firması için hayati derecede önemlidir (Yükselen, 2013; Koç, Şahin ve Özbek, 2014, 2014).

\section{Müşteri Memnuniyeti}

Bir işletmeden sürekli satın alma faaliyetinde bulunan kişi veya işletmelere müşteri denir (Çelik, 2012). Müşteri kavramı iç müşteri ve dış müşteri şeklinde ikiye ayrılır. Bir işletmede tedarikçilerden başlamak üzere dış müşterilere kadar devam eden süreç içerisinde birbirine ürün ve hizmet alanlara iç müşteri, işletmenin ürün ve hizmetini nihai tüketiciye kadar ulaştırılmasında yer alan tüm kullanıcılara dış müşteri adı verilir (Taşlıyan, 2007).

Ürün ve/veya hizmetin temel fonksiyonu, müşterilerin istek ve ihtiyaçlarını karşılamaktır (Tütüncü ve Doğan, 2003) ve tüketiciler genellikle ihtiyaçlarını karşılamak amacıyla değişik ürün ve hizmet çeşitliliği arasında tercih yapma durumu ile karşı karşıya kalırlar (Özer ve Günaydın, 2010).

Memnuniyet müşterilerin uzun vadede davranışlarını belirleyen unsurlardan biri olarak görülmektedir. Memnuniyet genel olarak, "müşterinin arzu ettiği, beklediği hizmete verdiği bir yanıt veya bir mal ya da hizmetin bizzat kendisinin alt veya üst düzeyde karşılama dereceleri de dâhil olmak üzere hoş (zevk veren) düzeyde tüketimle ilişkili karşılama veya yerine karşılıyor olmaya ilişkin bir yargı" olarak ifade edilmektedir (Emir, Kılıç ve Pelit, 2010). Müşteri memnuniyeti kavramı ise, belirli bir işlemin veya alışverişin yapılmasından sonra yapılan değerlendirme olarak açıklanabilir (İlter, 2009). Diğer bir tanımlamaya göre ise ürün veya hizmetin tüketimi boyunca, müşteri ihtiyaç, istek ve beklentilerinin bir sonraki ürün veya hizmet talebini ve ürün ya da hizmete bağlılığını etkileyen karşılanma derecisi olarak ifade edilir (Kılıç ve Pelit, 2004). 
Müşteri memnuniyeti müşterinin bir mal ya da hizmetten beklediği faydalara, mal ya da hizmetten beklediği performansa, katlanmaktan kurtulduğu külfetlere, soysa-kültürel değerlerine uygunluğuna bağlı bir fonksiyondur (Bayuk ve Küçük, 2007). Müşteri memnuniyeti fiziksel mallarda satın almadan sonra ürünün kalite, ihtiyaca uygunluk, performans vb. açılardan değerlendirilmesiyle ortaya çıkarken hizmetlerde ise hizmetin sunumu sırasında müşterinin beklentilerinin karşılanması sonucu ortaya çıkmaktadır (Özgüven, 2008). Müşterinin satın alacağı bir mal veya hizmetten beklentisi ile satın almadan sonra mal veya hizmetten sağladığı performans arasında uyum söz konusu olduğunda tatmin, tam tersi durumda ise tatminsizlik meydana gelir (Usta ve Memiş, 2009). Tatmin ya da tatminsizlik sonucu oluşan duygular müşterinin ürün ya da hizmeti tekrar satın alıp almamasına (Özgüven, 2008) ve ürün ya da hizmetle ilgili olumlu veya olumsuz düşüncelerini başkalarına yansıtmasına neden olur (Tikici ve Türk, 2003).

Hizmetlerin başta soyut olma ve diğer kendine ait özellikleri nedeniyle memnuniyet sağlamak daha zorlaşmakta ancak sağlandığı takdirde getirileri büyük olmaktadır. Yüksek bir müşteri memnuniyeti işletmeye müşteri sadakatini artırma, müşterilerin fiyat hassasiyetini düşürme, başarısız pazarlama ve yeni müşteri oluşturma maliyetlerini azaltma, müşteri sayılarının artması nedeniyle işletme maliyetlerini düşürme, reklam etkinliği ve ticari itibarı geliştirme gibi pek çok fayda sağlar (Kim, Park ve Jeong, 2004).

Literatürde hizmet kalitesi ile müşteri memnuniyeti arasındaki ilişkinin tespitine yönelik başta muhasebe sektörü ve diğer hizmet sektörüne yönelik çalışmalar mevcuttur.

Muhasebe meslek mensubunun ödeme (ücret), çalışan, eksik (yanlış) bilgi sunumu, yardımsever olmama ve küçük işletmelerin isteklerinin önemsenmemesi gibi hataların algılanan kaliteyi olumsuz etkileyeceği ve bunun sonucunun da memnuniyette azalma meydana getirebileceği yapılan araştırmalar sonucunda elde edilen bir bulgudur (Koç, Şahin ve Özbek, 2014). Saxby, Ehlen ve Koski, (2004) muhasebe firmaları tarafından sunulan hizmet kalitesinin müşteri memnuniyetinden olumlu, firma/müşteri çatışmasından olumsuz yönde etkilendiğini, müşteri memnuniyeti açısından güvenirlilik ile güven hizmet kalitesi boyutlarının daha önemli olduğunu, Ismail, Haron, Ibrahim ve Isa, (2006) müşteri memnuniyetini sırasıyla fiziksel özellikler, güvenilirlik ve empati boyutlarının olumlu yönde etkilediğini, güvenilirlik boyutunun müşteri bağlılı̆̆ını arttırdığını ve muhasebe meslek mensuplarının mesleki bilgi ile iletişim becerileri açısından yetersiz olduklarını ortaya koymuştur. Yayla ve Cengiz (2006) algılanan hizmet kalitesini sırasıyla güvence, fiziki görünüm, heveslilik, güvenlilik ve empati boyutlarının etkilediğini, ayrıca algılanan hizmet kalitesi ile müş̧teri memnuniyeti arasında ilişki olduğunu, Ağa ve Şafaklı (2007) firma imajının ve hizmet kalitesinin müşteri memnuniyetini olumlu yönde etkilediğini, hizmet fiyatının doğrudan hizmet kalitesini ve hizmet kalitesi boyutlarından sadece empati boyunun müşteri memnuniyetini etkilediğini, Banar ve Ekergil (2010) müşteri memnuniyetini hizmet kalitesi boyutlarından güvenilirlik, empati ve fiziksel özellik boyutlarının etkilediği tespit etmişlerdir. Erol (2007) muhasebe meslek elemanları tarafından sunulan hizmetler ile müşteri memnuniyeti arasındaki ilişkiyi Servqual'den farklı bir ölçek kullanarak tespit etmeye çalışmıştır. Yaptığı çalışmada iletişim, sorumluluk, bilgi ve davranıştan oluşan dört hizmet kalitesi boyutunu tespit etmiş ve bu özellikleri sahip muhasebe elemanlarının müşterilerini daha fazla memnun edeceklerini ifade etmiştir. Türk (2009) tarafından Servqual'den farklı olarak Servperf ölçeği kullanılarak yapılan çalışmada algılanan hizmet kalitesi, müşteri memnuniyeti ve sadakat arasındaki ilişki tespit edilmeye 
çalışılmıştır. Yaptığ çalışma ile: algılanan hizmet kalitesinin müşteri tatminini ve sadakati, müşteri tatmininin de sadakati anlamlı ve pozitif yönde etkilediğini tespit etmiştir.

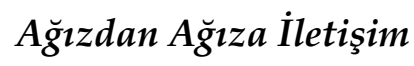

İletişim, insanın varlık sürdürme biçiminin bir ürünü ve insanın varlık sürdürme biçimindeki gelişmelere göre değişimlere uğrayan insana özgü bir olgu ve paylaşılan bir yaşamın olmazsa olmaz unsurudur. Söz konusu paylaşımlar, insanlar arasındaki duygu, düşünce, bilgi, birikim, ses, koku gibi öğeleri içinde barındırır (Taşoğlu, 2009). Genel olarak ele alındığında, iletişim, bir mesaj (haber) veya bir bilginin hedef alıcıya iletilmesi veya gönderilmesi şeklinde tanımlanır. İletişim; kişiler, gruplar ve örgütler arasında karşılıklı mesaj (düşünce, bilgi, haber) değişim süreci olarak tanımlanmaktadır (Avcılar, 2005).

Günümüzde tüketicilerin elde etmek istedikleri mal ve hizmetler ile ilgili bilgileri ailesinden, arkadaş sohbetlerinden, gazete ve özellikle internette var olan diğer bilgi platformlarından alabilmesi ağızdan ağıza iletişim kavramının önemini arttırmıştır (Türker, 2014).

Arndt ağızdan ağıza iletişimi; "ticari olmayan bir şekilde bir marka, ürün veya hizmetle ilgilenen iki veya daha fazla sayıda tüketici arasında sözlü iletişim şekli" olarak ifade etmiştir (Woodside ve Deloizer, 1976; Buttle, 1998). Bir başka tanıma göre ağızdan ağıza iletişim, malların ve hizmetlerin değerlendirilmesiyle ilgili olarak belirli kişiler arasında gerçekleşen resmi olmayan bir iletişim türü" şeklindedir (Belanche, Casalo ve Flavian, 2010). Diğer bir tanımlamaya göre ise ağızdan ağıza iletişim; "ürün sağlayıcısı, bağımsız uzmanlar, aile, arkadaşlar, gerçek ya da potansiyel tüketici gibi gruplar arasındaki olumlu veya olumsuz sözel iletişim şekli" olarak ifade edilmektedir (Ennew, Banerjee ve Li, 2000).

Gündelik yaşamda insanlar ürünler, hizmetler veya markalar hakkında konuşurlar, yorum yaparlar, değerlendirmelerde ve tavsiyelerde bulunurlar (Kalpaklığlu, 2015). Bu nedenle ağızdan ağıza iletişim tüketicilerin davranışları, farkındalıkları, beklentileri, algılamaları, tutumları ve davranışsal niyetleri üzerinde çok fazla etkiye sahiptir (Buttle, 1998). Hizmetler sektöründe, hizmetlerin özel nitelikleri (soyutlanma, ayrılmazlık, heterojenlik, bozulabilirlik) nedeniyle tüketiciler ürün/hizmet sunumu hakkında bilgi arama, değerlendirme ve daha sonraki karar alma süreçlerinde daha fazla bilgiye ihtiyaç duyduklarında, karşılaştırma için sınırlı bir zamanı olduğunda ve algılanan riskin azaltmak istediklerinde özellikle önemli satın alım tercihlerinde reklam vb. kaynaklar yerine kişisel iletişim kaynaklarına (diğer tüketicilere) güvenmeyi daha çok tercih ederler (Brown, Broderick ve Lee, 2007; Sweeney, Soutar ve Mazzarol, 2008; Chaniotakis ve Lymperopoulos, 2009; Belanche, Casalo ve Flavian, 2010).

Ağızdan ağıza iletişim tüketicileri markalara geçiş yapmaya yönlendiren gazete ve dergilerden yedi kat, kişisel satıştan dört kat ve radyo reklamcılığından iki kat daha fazla etkili olduğu araştırmalarda ortaya konulmuştur (Brown ve Reingen, 1987).

Ağızdan ağıza iletişim olumlu ya da olumsuz olabilir. Olumlu ağızdan ağıza iletişim birçok pazarlamacı tarafından belki de en eski pazarlama iletişim biçimlerinden biri olarak görülür (Chaniotakis ve Lymperopoulos, 2009). Olumlu ağızdan ağıza iletişim şirket tarafından aranan iyi haberler ve onaylar verildiğinde ortaya çıkar. Müşteri şikâyet davranış biçimlerinden birisi olarak da düşünülen negatif ağızdan ağıza iletişim (Derbaix ve Vanhamme, 2003) olumsuz geribildirim veya görüşleri aileyle, arkadaşlarla veya diğer kişilerle paylaşma çabası olarak tanımlanır (Balaji, Khong ve Chong, 2016). Diğer bir tanıma göre ise ürünle ilgili bir pazarlama organizasyonu veya iletişim nesnesini reddeden kişilerarası iletişim şeklinde tanımlanır (Laczniak, Decarlo ve Ramaswami, 2001). 
Tüketiciler bir üründen elde ettikleri fayda ile bekledikleri fayda arasında uyum söz konusu olduğunda memnun olurlar. Bu durumun tam tersinde ise sonuç memnuniyetsizlik olur. Memnun olan tüketiciler olumlu bir şekilde konuşurlar ve firmaları diğer müşterilere tavsiye ederek firmanın ve ürünlerin/hizmetlerin reklamını yaparlar (Belanche, Casalo ve Flavian, 2010). Memnun kalmış müşterilerin olumlu yorumları daha spesifik alımları arttırarak (Chaniotakis ve Lymperopoulos, 2009) pazarlama harcamalarını azaltmakla kalmayıp aynı zamanda yeni müşteriler çekilmesi durumunda da gelirleri arttırır (Derbaix ve Vanhamme, 2003). Ayrıca olumlu ağızdan ağıza iletişim, hizmetin performansıyla ilgili fonksiyonel riski, finansal kayıplarla ilgili finansal riski, tüketicinin kendi sosyal çevresiyle olan etkileşimiyle ilgili olan psikolojik, sosyal ve zamana dayalı riskleri azaltmaktadır (Sweeney, Soutar ve Mazzarol, 2008).

Negatif ağızdan ağıza iletişim, diğer tüketicilere yardım etmek amacıyla fedakârlık, kaygı azaltılması, danışmanlık ve intikam amacıyla ortaya çıkar (Edison ve Geissler, 2011) ve olumlu ağızdan ağıza iletişimden daha güçlü bir etkiye sahiptir. Memnuniyetsiz müşterilerin olumsuz yorumları satın alımları azaltarak (Chaniotakis ve Lymperopoulos, 2009) potansiyel olarak bir firmanın marka imajına zarar verebilir (Balaji, Khong ve Chong, 2016). Desatnick'e göre aldığı hizmetten memnun olmayan müşterilerin \% 90'1 veya daha fazlası tekrar satın almaz veya geri gelmez. Daha da kötüsü, bu mutsuz müşterilerin her biri en az 9 kişiye bu olumsuzluğu anlatır (Buttle, 1998).

Ağızdan ağıza iletişimin tüketici davranışları üzerindeki etkisi son yirmi yılda ulusal veya uluslararası birçok farklı alanda farklı akademik çalışmalarda ortaya konulmaya çalışılmıştır. Sweeney, Soutar ve Mazzarol (2005) hizmet kalitesiyle ilgili yorumlarda olumlu ağızdan ağıza iletişimin daha fazla düşünülmüş ve daha bilişsel olduğu buna karşılık olumsuz ağızdan ağıza iletişimin ise memnuniyetsizlikle ilişkili olarak daha duygusal olduğunu, bir firma ile olumsuz bir deneyim yaşadıktan sonra, olumlu deneyimler taşıyanlara kıyasla, duygularını daha erken sunduklarını, Ferguson, Paulin ve Leiriao (2007) ise hizmet kalitesi ve müşteri memnuniyetinin olumlu ağızdan ağıza iletişime neden olarak tavsiye üzerinde önemli bir etkisi olduğunu, Marangoz (2007) ağızdan müşterilerin tekrar satın alma ve değiştirme niyetlerinde ağıza iletişimin etkili olduğunu, Chaniotakis ve Lymperopoulos (2009) müşteri memnuniyeti ile hizmet kalitesi boyutlarından sadece empatinin ağızdan ağıza iletişimi direkt etkilediğini, heveslilik, güvence ve fiziksel özelliklerin ise dolaylı olarak etkilediğini, Arlı (2012) algılanan hizmet kalitesine ilişkin dokuz faktör belirlediğini ve bunlardan 'fiziksel koşullar', 'heveslilik', 'güvenlik' ve 'empati' faktörlerinin tekrar tercih etme ve tavsiye etme niyetleri üzerinde etkisinin bulunduğu, ayrıca, genel memnuniyet düzeyi ile niyet değişkenleri arasında anlamlı bir ilişki olduğunu, Öz ve Uyar (2014) algılanan hizmet kalitesi ve müşteri memnuniyetinin tavsiye davranışı üzerinde etkili olduğunu, Eru ve Köroğlu (2015) mükelleflerin çevrelerinden gelen tavsiyelere önem verdiğini, birlikte iş yapmak istedikleri mali müşavir-muhasebeci hakkında yapılan olumlu ya da olumsuz yorumlar hakkında etkilendiklerini ve daha önce o mali müşavir-muhasebeci ile çalışanların görüşlerine göre hareket ettiklerini ve Akçi ve Kılınç (2015) pozitif ağızdan ağıza iletişimin bir hizmet mesleği olan muhasebe meslek elemanlarının müşteri portföyünü arttırmada önemli etkisinin olduğunu tespit etmişlerdir. 


\section{Yöntem}

\section{Araştırmanın Amacı}

$\mathrm{Bu}$ araştırmanın amacı muhasebe meslek mensuplarının vermiş olduğu hizmetten müşterinin algıladığı kalitenin müşteri memnuniyetini ve müşteri memnuniyetinin de ağızdan ağıza iletişimi etkileyip etkilemediğini ortaya çıkarmaktır.

\section{Araştırmanın Modeli}

Çalışmada SERVQUAL ölçeği kullanılarak, muhasebe meslek mensupları tarafından sunulan hizmetten müşterinin algıladığ1 kalitenin müşteri memnuniyetini ve müşteri memnuniyetinin de ağızdan ağıza iletişimi ne derecede etkilediğini ölçmeye yönelik hipotezler şu şekilde kurulmuştur.

$\mathrm{H}_{1}$ : Müşterilerin algıladığı hizmet kalitesi ile muhasebe meslek mensubunun oluşturduğu müşteri memnuniyeti arasında ilişki vardır.

$\mathrm{H}_{2}$ : Müşteri memnuniyeti ile ağızdan ağıza iletişim arasında ilişki vardır.

\section{Evren ve Örneklem}

Araştırma Aydın ilinde gerçekleştirilmiştir. Çalışmanın evrenini Aydın il merkezinde faaliyet gösteren 3.822 işletme oluşturmasına rağmen şube niteliğinde Aydın'da faaliyet gösteren ya da Aydın'da bir muhasebe mensubundan hizmet almayan, işletmenin büyüklüğü nedeniyle bünyesinde muhasebe birimi bulunan ve muhasebe hizmet işletmeleri evrenin dışında bırakılmıştır. Ayrıca, cevaplayıcıların işletme sahibi, ortağı veya işletmenin finansal bilgilerinde söz sahibi olan bir yetkili olmasına özen gösterilmiştir.

Örnekleme yöntemi olarak olasılığa dayalı olmayan örnekleme yöntemlerinden kolayda örnekleme kullanılmıştır. Literatürde örneklem büyüklügünün belirlenmesine yönelik çalışmalarda farklı tartışmalar ve öneriler mevcuttur. Bazı araştırmacılar örneklem büyüklüğünün belirlenmesinde kişi sayısının temel alınması gerektiğini öne sürerken, bazı araştırmacılar ise değişken (madde)/kişi sayısı oranına göre belirlenmesini öne sürmektedirler. Örneklem büyüklüğünün belirlenmesinde kişi sayısını temel alan çalışmalarda, 100 kişiyi zayıf, 200'ü orta, 300'ü iyi, 500'ü çok iyi ve 1000'i mükemmel olarak değerlendirilmektedir. Örneklem büyüklüğünü madde üzerinden belirleyen çalışmalarda, örneklem sayısının her madde için 3-6 kişi, en az 5 kişi, 5 kişi ile 10 kişi arası ya da en az 10 kişi olması gerektiği ileri sürülmektedir (Kesik ve Balc1, 2016). Araştırmada 275 işletmeyle yüz yüze anket çalışması yapılmış olup örneklem büyüklügü madde sayısının beş katından fazla olduğu için örneklem büyüklüğü ölçütünü karşıladığı söylenebilir.

\section{Veri Toplama Araçları}

Çalışmada veri toplama yöntemi olarak anket yöntemi kullanılmıştır. Anket dört bölümden meydana gelmektedir. Anketin ilk bölümünde demografik özelliklere ait 13 soru, ikinci bölümünde Banar ve Ekergil'in (2010) çalışmasında yer alan Saxby vd. tarafından muhasebe firmaları için uyarlanan 5 boyut (fiziksel özellikler, güvenilirlik, heveslilik, güven ve empati) ve 22 sorudan oluşan SERVQUAL ölçeği, üçüncü bölümünde müşteri memnuniyetini ölçmeyi amaçlayan bir soru ve dördüncü bölümünde ise ağızdan ağıza iletişimi ölçmeyi amaçlayan bir soru yer almaktadır. Ankette bulunan her bir soru için "1-Kesinlikle Katılmıyorum"dan başlayıp "5-Kesinlikle Katılıyorum" şeklinde derecelendirilen 5'li Likert ölçeği kullanılmıştır. 


\section{Verilerin Toplanması ve Analizi}

Çalışmanın teorik altyapısı veri tabanlarından ve internetten tarama yapılarak oluşturulmuştur. Anket çalışmasından elde edilen verilerin analizi için SPSS 22 paket programı kullanılmış ve verilerin normal dağıldığı kabul edilerek frekans, faktör analizi ve regresyon testlerine tabi tutulmuştur.

\section{Bulgular}

Ankete katılanların ve işletmeye ait demografik özelliklerin frekans analizi Tablo 1 ve Tablo 2'de gösterilmiştir.

Tablo 1'de yer alan veriler incelendiğinde, anketi cevaplayanların büyük bir kısmının erkek, ortaöğretim-lise mezunu ve 30-39 yaş aralığında, işletme sahibi ya da ortağ 1 ve işletmedeki çalışma süresinin ise 10 yıldan fazla olduğu anlaşılmaktadır. Tablo 2'deki işletmelerin demografik yapıları verileri incelendiğinde ise bu işletmelerin büyük çoğunluğunun 1-3 kişi arasında istihdam sağlayan tek kişi işletmesi olup perakende ticaretinde 2 ile 5 yıldan bu yana faaliyet gösterdiği, işletmenin aylık kazancının 1000-5000 Lira arasında olduğu ve genelde bir muhasebeci ile 2-5 yıldan bu yana çalışıldığı anlaşılmaktadır.

Tablo 1. Katılımcıların Demografik Özelliklerine ait Frekans Bilgileri

\begin{tabular}{|l|l|l|l|l|l|}
\hline Cinsiyet & F & $\%$ & İşletmedeki pozisyon & F & $\%$ \\
\hline Erkek & 183 & 66,5 & İş sahibi-Ortağı & 180 & 65,5 \\
\hline Kadın & 92 & 33,5 & Yönetici & 52 & 18,9 \\
\hline Yaş & & & Diğer & 43 & 15,6 \\
\hline $21-29$ & 71 & 25,8 & İşletmedeki Çalışma Süresi & & \\
\hline $30-39$ & 110 & 40,0 & 1 yıl altı & 37 & 13,5 \\
\hline $40-49$ & 94 & 34,2 & $2-3$ yıl arası & 60 & 21,8 \\
\hline Eğitim Durumu & & & $4-5$ yıl arası & 48 & 17,5 \\
\hline Ortaöğretim/Lise & 130 & 47,3 & $6-7$ yıl arası & 32 & 11,6 \\
\hline Önlisans/Lisans & 126 & 45,8 & $8-9$ yıl arası & 16 & 5,8 \\
\hline Yüksek lisans/Doktora & 19 & 6,9 & 10 yıl ve üstü & 82 & 29,8 \\
\hline
\end{tabular}


Tablo 2. İşletmenin Demografik Özelliklerine ait Frekans Bilgileri

\begin{tabular}{|c|c|c|c|c|c|}
\hline İşletmenin Faaliyet Sektörü & & & İşletmede Çalışan Sayısı & & \\
\hline Perakende Ticaret & 73 & 26,5 & 1-3 kişi & 183 & 66,5 \\
\hline Tekstil/Giyim & 15 & 5,5 & 4-7 kişi & 41 & 14,9 \\
\hline Yiyecek-İçecek & 24 & 8,7 & 8-11 kişi & 11 & 4,0 \\
\hline Ĕ̆itim & 3 & 1,1 & 12 ve üzeri & 40 & 14,5 \\
\hline Sağlık & 8 & 2,9 & İşletmenin Aylık Kazancı & & \\
\hline Kuyumculuk & 2 & ,7 & $1.001 \mathrm{TL}-5.000 \mathrm{TL}$ & 188 & 68,4 \\
\hline Bilişim-Elektronik & 40 & 14,5 & $5.001 \mathrm{TL}-10.000 \mathrm{TL}$ & 45 & 16,4 \\
\hline İnşaat & 15 & 5,5 & $10.001 \mathrm{TL}-20.000 \mathrm{TL}$ & 30 & 10,9 \\
\hline Reklamcilık & 3 & 1,1 & 20.001 TL - 50.000 TL & 12 & 4,4 \\
\hline Kuaför & 14 & 5,1 & Çalışılan Muhasebeci Sayısı & & \\
\hline Spor Merkezi & 5 & 1,8 & 1 & 171 & 62,2 \\
\hline Diğger & 73 & 26,5 & 2 & 63 & 22,9 \\
\hline İşletmenin Hukuki Yapısı & & & 3 & 30 & 10,9 \\
\hline Tek kişi işletmesi & 155 & 56,4 & 4 & 11 & 4,0 \\
\hline Adi ortaklık & 26 & 9,5 & En Son Muhasebeci ile Çalışma Süresi & & \\
\hline Şahıs şirketi & 53 & 19,3 & 1 yıl altı & 13 & 4,7 \\
\hline Sermaye şirketi & 41 & 14,9 & $2-5$ yıl arası & 139 & 50,5 \\
\hline Faaliyet Süresi & & & 6-9 yıl arası & 63 & 22,9 \\
\hline 1 y1l altı & 6 & 2,2 & $10-13$ yıl arası & 10 & 3,6 \\
\hline $2-5$ yil & 94 & 34,2 & $14-17$ yıl arası & 14 & 5,1 \\
\hline 6-10 yıl & 51 & 18,5 & 18 yıl ve üstü & 36 & 13,1 \\
\hline $11-15$ y1l & 45 & 16,4 & & & \\
\hline $16-20$ yil & 29 & 10,5 & & & \\
\hline 21 yıl ve üstü & 50 & 18,2 & & & \\
\hline
\end{tabular}


Çalışmada SERVQUAL ölçeğinin beş boyutu hem güvenilirlik hem de faktör analizine tabi tutulmuştur. Tablo 2' de görüldügü gibi hizmet kalitesini oluşturan boyutların güvenilirlik değerlerinin \%80'in üzerinde çıkması, yapılacak analizlerin sonuçlarının güvenilir olacağını ifade etmektedir.

Tablo 2. Hizmet Kalitesi Boyutlarının Güvenilirlik Analizleri

\begin{tabular}{|l|c|}
\hline Hizmet Kalitesi Boyutları & Güvenilirlik Katsayısı \% \\
\hline Fiziksel Özellikler & 86,3 \\
\hline Güvenilirlik & 87,7 \\
\hline Empati & 86,6 \\
\hline
\end{tabular}

Örneklem büyüklügünün yeterliliğini test eden Kaiser-Meyer-Olkin (KMO) testinin sonucu \%96,1 olarak çıkmıştır. Bu değerin 1'e yakın olması nedeniyle örneklem büyüklügünün yeterli olduğunu ve cevaplayıcıların anketi önemsediklerini, yanıtlarını büyük bir ciddiyetle verdiklerini göstermektedir.

Yapılan açıklayıcı faktör analizi testi sonucunda değişkenler teorik çalışmadan farklı olarak beş faktör yerine üç faktör altında toplanmıştır. Bu faktörler Tablo 3'de görüldüğü üzere güvenilirlik, empati ve fiziksel özellikler olarak adlandırılmıştır. Elde edilen bu üç faktör toplam varyansın \%66,14'ünü açıklamaktadır. Teorik çalışmada yer alan güven ve heveslilik faktörlerinin bu çalışmada güvenilirlik faktörü altında toplandığı tespit edilmiştir. Bu iki faktörün güvenilirlik faktörü altında toplanmasının nedeni Aydın ilinin hem coğrafi açıdan hem de işletme sayısı açısından küçük olması gösterilebilir. Çünkü küçük bir coğrafi alanda faaliyet gösteren işletmeler muhasebe hizmeti satın almak istediklerinde eş dost tavsiyesini dikkate alırlar. $\mathrm{Bu}$ da işletmeler ile muhasebe elamanları arasında daha fazla güvenin oluşmasına neden olur. Ayrıca büyük yerleşim yerlerine göre küçük yerleşim yerlerinde iletişim daha sıcak ve samimi ortamda gerçekleştiğinden bu güven daha da pekişir. Muhasebe alanında çalışanların bilgisi, müşteriyle doğru iletişim kurulması, hizmet kalitesinin önemli bir belirleyicisidir (Koç, Şahin ve Özbek, 2014). Bu bağlamda üçüncü sırada yer alan empati boyutunda bu özellikler toplanmıştır. Çalışmada fiziksel özellikler üçüncü sırada yer almıştır. Bir başka çalışmada bu durumun aksine muhasebe hizmeti alan müşterilerin kendilerine sunulan hizmetin kalitesini fiziksel boyutta beklentilerinin üstünde algıladığı ortaya konmuştur (Ustaoğlu, Aygün ve Savc1, 2013). 
Tablo 3. Hizmet Kalitesi Boyutlarının Faktör Analizi

\begin{tabular}{|c|c|c|c|c|}
\hline & $\mu$ & $\mathbf{S}$ & $\begin{array}{l}\text { Faktör } \\
\text { Yükü }\end{array}$ & $\begin{array}{l}\text { Açıklanan } \\
\text { Varyans }\end{array}$ \\
\hline FAKTÖR-1- Güvenilirlik & 4,37 & 0,756 & & 28,100 \\
\hline $\begin{array}{l}\text { Muhasebecim verdiği } \text { sözleri } \text { mutlaka yerine } \\
\text { getirir.GVN4 }\end{array}$ & 4,33 & 0,865 & 0,679 & \\
\hline $\begin{array}{l}\text { Muhasebecim kayitları yasalara ve mevzuata uygun } \\
\text { tutar.GVN5 }\end{array}$ & 4,37 & 0,837 & 0,636 & \\
\hline Muhasebecim güven veren bir kişidir.GVN3 & 4,40 & 0,854 & 0,583 & \\
\hline FAKTÖR-2- Empati & 4,16 & 0,783 & & 21,557 \\
\hline $\begin{array}{l}\text { Muhasebecimin çalışanları bana kişisel olarak ilgi ve } \\
\text { özen gösterirler.EMP2 }\end{array}$ & 4,20 & 0,789 & 0,573 & \\
\hline Muhasebecim bana kişisel olarak önem verir.EMP1 & 4,25 & 0,892 & 0,551 & \\
\hline $\begin{array}{llll}\text { Muhasebecimin çalışma } & \text { saatleri } & \text { benimkiyle } \\
\text { uyumludur.EMP5 } & & \end{array}$ & 4,03 & 1,075 & 0,542 & \\
\hline FAKTÖR-3-Fiziksel Özellikler & 4,12 & 0,849 & & 16,485 \\
\hline $\begin{array}{l}\text { Muhasebecimin kullandığı araç gereçler teknolojiye } \\
\text { uygundur.F1 }\end{array}$ & 4,13 & 0,981 & 0,798 & \\
\hline $\begin{array}{l}\text { Muhasebecimin bürosunun fiziksel özellikleri göze } \\
\text { hitap etmektedir.F2 }\end{array}$ & 4,06 & 1,063 & 0,781 & \\
\hline $\begin{array}{l}\text { Muhasebecimin kullandığı büro malzemeleri verilen } \\
\text { hizmetler için yeterlidir.F4 }\end{array}$ & 4,17 & 0,874 & 0,720 & \\
\hline
\end{tabular}

Faktör analizi sonucu tespit edilen hizmet kalitesinin üç boyutunun müşterilerin memnuniyetini nasıl etkilediği sorusuna yanıt aramak amacıyla, hizmet kalitesinin üç boyutunun her birinin değerleri ile müşteri memnuniyet değerleri regresyon analizine tabi tutulmuş ve bu durum Tablo 4' de gösterilmiştir. 
Tablo 4. Hizmet Kalitesi Müşteri Memnuniyetinin Regresyonu (Bağımlı Değişken: Müşteri

Memnuniyeti Değerleri)

\begin{tabular}{|l|c|c|c|c|c|}
\hline \multicolumn{1}{|c|}{ Model } & $\begin{array}{c}\text { Standardize Edilmemiş } \\
\text { katsayılar }\end{array}$ & $\begin{array}{c}\text { Standart } \\
\text { Hata }\end{array}$ & $\begin{array}{c}\text { Standardize Edilmiş } \\
\text { Katsayılar }\end{array}$ & $\mathbf{t}$ & $\mathbf{p}$ \\
\hline Sabit Terim &, 242 &, 212 & -- & 1,139 &, 256 \\
\hline Güvenilirlik &, 225 &, 069 &, 192 & 3,247 &, $001^{*}$ \\
\hline Empati &, 474 &, 069 &, 419 & 6,883 &, $000^{*}$ \\
\hline $\begin{array}{l}\text { Fiziksel } \\
\text { Özellikler }\end{array}$ &, 259 &, 058 &, 248 & 4,476 &, $000^{*}$ \\
\hline
\end{tabular}

$\mathrm{P}<0,01$ anlamlılık düzeyinde

\begin{tabular}{|c|c|c|}
\hline Belirlilik Katsayısı $\left(\mathbf{R}^{2}\right)$ & Düzeltilmiş Belirlilik Katsayısı (Düz-R²) & Tahminlerin Standart Hatası \\
\hline, 590 &, 586 & 0,57039 \\
\hline
\end{tabular}

Hizmet kalitesinin "güvenilirlik", "empati" ve "fiziksel özellikler" boyutları ile müşteri memnuniyeti $\mathrm{p}<.001$ anlamlılık düzeyinde regresyona tabi tutulması sonucu her üç faktör boyutunun da müşteri memnuniyetini olumlu yönde etkilediği tespit edilmiştir. Düzeltilmiş $\mathrm{R}^{2}$, hizmet kalitesinin müşteri memnuniyetini \%58,6 oranında değiştirdiğini açıklamaktadır. Yapılan analizin sonucu H1 hipotezini desteklemektedir. Ağa ve Şafaklı (2007) Kuzey Kıbrıs'taki profesyonel muhasebe firmalarının müşteri memnuniyeti ile hizmet kalitesini inceledikleri çalışmada, müşteri memnuniyetini hizmet kalitesi boyutlarından sadece "empati" değişkeninin etkilediğini ortaya koymuştur.

Muhasebe meslek mensubunun güvenilir, sorumluluğunu bilen ve kendi her konuda yetiştirmesi beklenir. Özellikle muhasebe elemanlarının yapacakları işler ve düzenleyecekleri belgelerin şekli ve içerikleri kanunlar çerçevesinde belirlenmiştir. Bu nedenle devlet ile işletmeler arasında köprü görevi gören muhasebe meslek mensuplarının uymak zorunda oldukları etik kurallar gerek uluslararası gerekse ulusal kuruluşlar tarafından düzenlenmiştir. Bu nedenle muhasebe meslek elamanları hiçbir çıkar gözetmeksizin güvenilirlik ve tarafsızlık vasıflarıyla müşteriye hizmet sunarken kamu yararını gözetmelidir.

Muhasebe meslek mensuplarının hizmet kalitesi alt boyutlarının hangisinin ya da hangilerinin müşteri memnuniyetini etkilediğini belirlemek amacıyla, öncelikle güvenilirlik boyutunun unsurları ile müşteri memnuniyeti bağımlı değişkeni regresyona tabi tutulmuş olup analiz sonuçları Tablo 5'de gösterilmiştir. 
Tablo 5. Hizmet Kalitesinin Güvenilirlik Boyutu Unsurlarının Müşteri Memnuniyeti Analizi

\begin{tabular}{|l|c|c|c|c|c|}
\hline \multicolumn{1}{|c|}{ Model } & $\begin{array}{c}\text { Standardize } \\
\text { Edilmemiş } \\
\text { katsayılar }\end{array}$ & $\begin{array}{c}\text { Standart } \\
\text { Hata }\end{array}$ & $\begin{array}{c}\text { Standardize } \\
\text { Edilmiş } \\
\text { Katsayılar }\end{array}$ & $\mathbf{T}$ & $\mathbf{p}$ \\
\hline Sabit Terim &, 952 &, 233 & --- & 4,083 &, 000 \\
\hline $\begin{array}{l}\text { Muhasebecim verdiği sözleri } \\
\text { mutlaka yerine getirir.GVN4 }\end{array}$ &, 248 &, 073 &, 242 & 3,390 &, $001^{*}$ \\
\hline $\begin{array}{l}\text { Muhasebecim kayıtları } \\
\text { yasalara ve mevzuata uygun } \\
\text { tutar.GVN5 }\end{array}$ &, 000 &, 067 &, 033 &, 520 &, 604 \\
\hline $\begin{array}{l}\text { Muhasebecim güven veren bir } \\
\text { kişidir.GVN3 }\end{array}$ &, 460 &, 070 &, 456 & 6,742 &, $000^{*}$ \\
\hline
\end{tabular}

$\mathrm{P}<0,01$ anlamlılık düzeyinde

\begin{tabular}{|c|c|c|}
\hline Belirlilik Katsayısı $\left(\mathbf{R}^{2}\right)$ & Düzeltilmiş Belirlilik Katsayısı (Düz-R²) & Tahminlerin Standart Hatası \\
\hline 459 & 453 & 65551 \\
\hline
\end{tabular}

Güvenilirlik boyutunun unsurlarından olan muhasebecim verdiği sözleri mutlaka yerine getirir ve muhasebecim güven veren bir kişidir sorularına verilen cevaplar $\mathrm{p}<.001$ anlamlılık düzeyinde anlamlı olduğu tespit edilmiştir. Analiz sonucu bu iki unsurun müşteriler tarafından müşteri memnuniyetini arttırdığ güvenilirlik boyutunun müşteri memnuniyetini \%45,9 oranında ilişkili olması ile de desteklenmektedir. Güvenilirlik boyutunun önemli unsurlarından birisi olan "muhasebecim kayıtları yasalara ve mevzuata uygun tutar" bileşeninin istatistiksel olarak anlamlı çıkmadığı Tablo 5'de görülmektedir. Dolayısıyla muhasebe kayıtlarının yasalara ve mevzuata uygun olarak tutulmaması hizmet kalitesini etkilemektedir.

Saxby, Ehlen ve Koski (2004), bağımsız denetim firmalarının hizmet kalitesinin güvenlik ve güvenilirlik boyutları ile müşteri memnuniyetinin artırıldığını belirtmiş, hizmet kalitesinde "güvenlik" boyutunun hem müşteri memnuniyetinde hem de müşteri/firma çatışmasında önemli bir role sahip olduğu ortaya koymuştur. Türkiye'de yapılan bir çalışmada algılanan hizmet kalitesinin güvenilirlilik alt boyutu itibariyle müşteri memnuniyeti üzerinde pozitif düzeyde anlamlı etkisi olduğu tespit edilmiştir (Taysı ve Canbaz, 2017).

Günümüzde ticari hayatın sürekli olarak gelişmesi nedeniyle yapılan işlerin niteliği ve mahiyeti de değişmektedir. Bu nedenle hem ticari kanunda hem de vergi kanunlarında devamlı olarak yeni düzenlemeler yapılmaktadır. İşletme sahip ve ortaklarının bu düzenlemeleri takip etmeleri ve anlamaları mümkün değildir. Bu nedenle alanında iyi eğitim almış muhasebe meslek mensubu elemanları sürekli olarak güncellenen mevzuatı takip ederek kendini geliştirmesi gerekmektedir. Muhasebe işlemenin lisanı olarak kabul edilmektedir. Bu nedenle işletme sahiplerinin muhasebede üretilen sonuçları anlaması ve kullanabilmesi gerekmektedir. Dolayısıyla muhasebe meslek mensupları müşterileri ile iletişim kurarak, muhasebe verilerinden elde edilen finansal sonuçları müşterilerinin 
anlayabileceği bir dilde açılamaları gerekmektedir. İletişim kurma, yeterlilik, müşterileri anlama ve erişim empati boyutunun alt unsurlarını oluşturmaktadır. Muhasebe meslek mensuplarının empati boyutunu oluşturan unsurlarından hangisinin ya da hangilerinin müşteri memnuniyetini etkilediğini belirlemek amacıyla, empati boyutunun unsurları ile müşteri memnuniyeti bağımlı değişkeni regresyona tabi tutulmuştur. Bu durum Tablo 6' da gösterilmiştir.

Tablo 6. Hizmet Kalitesinin Empati Boyutu Unsurlarının Müşteri Memnuniyeti Analizi

\begin{tabular}{|l|c|c|c|c|c|}
\hline \multicolumn{1}{|c|}{ Model } & $\begin{array}{c}\text { Standardize } \\
\text { Edilmemiş } \\
\text { katsayılar }\end{array}$ & $\begin{array}{c}\text { Standart } \\
\text { Hata }\end{array}$ & $\begin{array}{c}\text { Standardize } \\
\text { Edilmiş } \\
\text { Katsayılar }\end{array}$ & $\mathbf{T}$ & $\mathbf{p}$ \\
\hline Sabit Terim & 1,032 &, 209 & --- & 4,930 &, 000 \\
\hline $\begin{array}{l}\text { Muhasebecimin çalışanları bana } \\
\text { kişisel olarak ilgi ve özen } \\
\text { gösterirler.EMP2 }\end{array}$ &, 149 &, 063 &, 132 & 2,379 &, 018 \\
\hline $\begin{array}{l}\text { Muhasebecim bana kişisel olarak } \\
\text { önem verir.EMP1 }\end{array}$ &, 266 &, 060 &, 268 & 4,460 &, $000^{*}$ \\
\hline $\begin{array}{l}\text { Muhasebecimin çalışma saatleri } \\
\text { benimkiyle uyumludur.EMP5 }\end{array}$ &, 366 &, 044 &, 443 & 8,370 &, $000^{*}$ \\
\hline
\end{tabular}

$\mathrm{P}<0,01$ anlamlılık düzeyinde

\begin{tabular}{|c|c|c|}
\hline Belirlilik Katsayısı $\left(\mathbf{R}^{2}\right)$ & Düzeltilmiş Belirlilik Katsayısı (Düz-R²) & Tahminlerin Standart Hatası \\
\hline ,535 & ,530 & 60731 \\
\hline
\end{tabular}

Müşteriler, muhasebecilerinin kişisel olarak kendilerine önem vermesi ve çalışma saatleri ile kendi çalışma saatleri arasındaki uyumun müşteri memnuniyetini arttırdığını ifade etmektedir. $\mathrm{Bu}$ durum düzeltilmiş $\mathrm{R}^{2}$, empati boyutunun müşteri memnuniyetini \%53,0 oranında ilişkili olduğunu açklamaktadır. Bununla birlikte, empati boyutunun unsurlarından birisi olan muhasebecimin çalışanları bana kişisel olarak ilgi ve özen gösterirler sorusunun istatistiksel olarak anlamlı çıkmadığı Tablo 6'da görülmektedir. Bu durum muhasebe bürosunda çalışanların müşterilerle yeterli iletişim kuramadığını ve erişim konusunda bazı sıkıntıların yaşandığını göstermektedir.

Muhasebe meslek mensuplarının fiziksel özellikler boyutunu oluşturan unsurlarından hangisinin ya da hangilerinin müşteri memnuniyetini etkilediğini belirlemek amaciyla, fiziksel özellikler boyutunun unsurları ile müşteri memnuniyeti bağımlı değişkeni regresyona tabi tutulmuş olup analiz sonucu Tablo 7'de gösterilmiştir. 
Tablo 7. Hizmet Kalitesinin Fiziksel Özellikler Boyutu Unsurlarının Müşteri Memnuniyeti

Analizi

\begin{tabular}{|l|c|c|c|c|c|}
\hline \multicolumn{1}{|c|}{ Model } & $\begin{array}{c}\text { Standardize } \\
\text { Edilmemiş } \\
\text { katsayılar }\end{array}$ & $\begin{array}{c}\text { Standart } \\
\text { Hata }\end{array}$ & $\begin{array}{c}\text { Standardize } \\
\text { Edilmiş } \\
\text { Katsayılar }\end{array}$ & $\mathbf{t}$ & $\mathbf{p}$ \\
\hline Sabit Terim & 1,445 &, 206 & -- & 7,007 &, 000 \\
\hline $\begin{array}{l}\text { Muhasebecimin kullandığı araç } \\
\text { gereçler teknolojiye uygundur.F1 }\end{array}$ &, 350 &, 062 &, 687 & 5,622 &, $000^{*}$ \\
\hline $\begin{array}{l}\text { Muhasebecimin bürosunun } \\
\text { fiziksel özellikleri göze hitap } \\
\text { etmektedir.F2 }\end{array}$ &, 140 &, 052 &, 168 & 2,702 &, $007^{*}$ \\
\hline $\begin{array}{l}\text { Muhasebecimin kullandığı büro } \\
\text { malzemeleri verilen hizmetler } \\
\text { için yeterlidir.F4 }\end{array}$ &, 192 &, 065 &, 190 & 2,939 &, $004^{*}$ \\
\hline
\end{tabular}

$\mathrm{P}<0,01$ anlamlılık düzeyinde

\begin{tabular}{|c|c|c|}
\hline Belirlilik Katsayısı (R²) & Düzeltilmiş Belirlilik Katsayısı (Düz-R $)$ & Tahminlerin Standart Hatası \\
\hline, 437 &, 431 &, 66850 \\
\hline
\end{tabular}

Müşterilerin, muhasebe mensubunun bürosunun genel görünüş açısından, kullanılan büro malzemelerinin yeterliliği açısından ve araç gereçlerin teknolojik açıdan yeterli buldukları Tablo 7'deki anlamlılık düzeylerinden anlaşılmaktadır. Düzeltilmiş $\mathrm{R}^{2}$ değerine bakarak fiziksel özellikler boyutunun diğer boyutlara göre müşteri memnuniyetini daha az etkilediği ifade edilebilir. Özellikle son yıllarda teknolojide yaşanan yenilikler muhasebe alanında da yaşanmış ve ortaya çıkarılan paket programlar sonucunda muhasebe bilgi ve belgelerinin kayıtları hızlı ve güvenilir bir şekilde yapılmaya başlanmıştır. Ayrıca e-devlet uygulaması ile kurumlar arası koordinasyonun internet veri tabanından sağlanması bu süreci daha da hızlandırmıştır. Bu nedenle müşteriler muhasebe meslek elemanlarının yeterli teknolojik donanıma sahip olmaları gerektiğini önemsedikleri analiz sonucundan anlaşılmaktadır.

Hizmetlerin soyut özellik taşıması nedeniyle sunulan hizmetlerin her şeyden önce müşteri algısında olumlu izlenimler yaratması gerekmektedir. Hizmet sektörünün bir parçası olan muhasebe meslek mensupları da bu amaç doğrultusunda müşteri istek ve arzularını arttıracak kaliteli hizmet sunmaya çalışırlar. Yapılan çalışmalarda ağızdan ağıza iletişimin müşteri memnuniyeti ile ilişkili olduğunu kanıtlanmıştır. Araştırma sonuçları sunulan hizmetten memnun olmayan müşterilerin olumsuz yorumlar yaparak müşteri kaybına neden olduğu, olumlu yorumların ise müşteriyi elde tutma ya da yeni müşteriler kazanma açısından etkili olduğunu göstermektedir. Dolayısıyla hem hizmetin devamlılığı hem de yeni müşteriler elde etme açısından muhasebe hizmeti satın alan müşterilerin memnuniyeti zorunluluk haline gelmektedir. Bu nedenle müşteri memnuniyeti verileri ile ağızdan ağıza iletişim verileri arasında ilişki olup olmadığını test etmek amacıyla her iki değişken regresyon analizine tabi tutulmuştur. Analiz sonuçları Tablo 8' de gösterilmektedir. 
Tablo 8. Müşteri Memnuniyeti - Ağızdan Ağıza İletişim Regresyonu (Bağımlı Değişken:

Ağıdan A ̆̆ıza İletişim Değerleri)

\begin{tabular}{|l|c|c|c|c|c|}
\hline \multicolumn{1}{|c|}{ Model } & $\begin{array}{c}\text { Standardize Edilmemiş } \\
\text { katsayılar }\end{array}$ & $\begin{array}{c}\text { Standart } \\
\text { Hata }\end{array}$ & $\begin{array}{c}\text { Standardize Edilmiş } \\
\text { Katsayılar }\end{array}$ & $\mathbf{t}$ & $\mathbf{p}$ \\
\hline Sabit & 1,572 &, 161 & --- & 9,776 &, $000^{*}$ \\
\hline AAi &, 634 &, 037 &, 720 & 17,161 &, $000^{*}$ \\
\hline
\end{tabular}

$\mathrm{P}<0,01$ anlamlılık düzeyinde

\begin{tabular}{|c|c|c|}
\hline Belirlilik Katsayısı (R²) & Düzeltilmiş Belirlilik Katsayısı (Düz-R $\left.{ }^{2}\right)$ & Tahminlerin Standart Hatası \\
\hline, 519 &, 517 &, 54173 \\
\hline
\end{tabular}

Müş̧teri memnuniyeti ile ağızdan ağıza iletişim verileri $p<.001$ anlamlılık düzeyinde regresyona tabi tutulmuş ve analiz sonucu müşteri memnuniyetinin ağızdan ağıza iletişimi olumlu yönde etkilediği tespit edilmiştir. Düzeltilmiş $\mathrm{R}^{2}$, müşteri memnuniyetinin ağızdan ağıza iletişim üzerinde \%51,7 oranında etkili olduğunu açıklamaktadır. Yapılan analiz sonucu $\mathrm{H}_{2}$ hipotezini desteklemektedir.

\section{Sonuç}

Hizmet işletmeleri tarafından müşterilere sağlanan hizmetlerin diğer sektörlerde üretilen ürünlerinden farklı özellikler taşıması hizmet kalitesinin ölçülmesini zorlaştırmaktadır. Hizmet kalitesinin ölçülmesine yönelik olarak en çok kullanılan yöntem PZB tarafından geliştirilen SERVQUAL ölçeğidir. Hizmet işletmeleri tarafından sunulan hizmetin kalitesi müşteri memnuniyetini arttıran bir unsurdur. Müşteri memnuniyeti bu işletmelerin mevcut müşterilerini elde tutma veya yeni müşteriler kazanmasında önemli bir rol oynayan ağıdan ağıza iletişim üzerinde etkilidir. Bu nedenle muhasebe meslek mensupları tarafından sunulan hizmetin kalitesinin SERVQUAL ölçeğinin beş boyutundan hangisinin daha etkin rol oynadığının belirlenmesi gerekmektedir. Dolayısıyla, muhasebe meslek mensuplarının hizmet kalitesini arttıran veya olumsuz etkileyen boyut/boyutların müşteriler tarafından nasıl algılandığının araştırılması gerekecektir.

Çalışmada, Aydın ilinde faaliyette bulunan ve muhasebe bürolarından hizmet alan işletmelerin, sunulan hizmet kalitesini güvenilirlik, empati ve fiziksel özellikler boyutlarında algıladıkları tespit edilmiştir. Teorik çalışmada var olan güven ve heveslilik boyutların bu çalışmada güvenilirlik boyutu altında toplandığı tespit edilmiştir. Bunun önemli bir nedeni muhasebe hizmeti satın alınan işletmelerin yeterince kurumsal olmamalarıdır. Özellikle kurumsallaşmanın getirdiği profesyonel yönetim anlayışının olmaması, çalışanların seçiminde titiz davranılmaması ve müşterilerle yeterli iletişimin sağlanamaması bu iki boyutun güvenilirlik boyutunun altında toplanmasına neden olmuştur. Muhasebe meslek mensuplarının müşteri memnuniyetini daha da artırabilmeleri ancak kurumsallaşma ile mümkündür. Kurumsallaşma ile işletme yürütmekte olduğu faaliyetlerini daha profesyonel bir temele oturtur, pazarın dinamiğine uyum sağlar, daha düzenli ve sistemli çalışır, hata yapma oranı azalır, çalışanlar dikkatli seçildiğinden verimlilik artar, tüm çalışanların hem 
kendi aralarında hem de işletme çevresiyle iletişimi artar. Bu durum müşteri memnuniyetine olumlu etki eder.

Yapılan çalışmada, hizmet kalitesinin oluşturan güvenilirlik, empati ve fiziksel özellikler boyutlarının müşteri memnuniyeti ile ilişkisi incelendiğinde sırasıyla empati, güvenilirlik ve fiziksel özelliklerin müşteri memnuniyetini artırdığı tespit edilmiştir. Güvenilirlik boyutu unsurlarından muhasebecim verdiği sözleri mutlaka yerine getirir ve muhasebecim güven veren bir kişidir sorularına verilen cevapların anlamlı olduğu "muhasebecim kayıtları yasalara ve mevzuata uygun tutar" unsurunun ise istatistiksel olarak anlamlı olmadığ tespit edilmiştir. Sonuçta müşteri memnuniyetini olumsuz etkileyen doğruluk bileşenine muhasebe meslek mensupları tarafından yeterince önem verilmediği ortaya çıkmaktadır. Bu nedenle muhasebe meslek mensuplarının muhasebe bilgi seviyesini arttırarak müşteri memnuniyetini arttırmaları gerekmektedir.

Müşterilerin anket sorularına verdiği yanıtlardan muhasebe çalışanlarının ilgi ve özen konusunda yetersiz olduğu tespit edilmiştir. Empati boyutu müşteri memnuniyeti etkileyen en önemli unsurlardan birisidir. Müşterilerin istediği hizmeti dilediği kalitede sunabilmek için gerekli olan istek ve beklentilerin ne olduğunun anlaşılması büyük önem taşımaktadır. Mali müşavir, müşterisi ile sürekli iletişimde bulunmalı, sadece ödeme zamanı ziyaret etmek yerine belirli periyotlarla ziyaretler gerçekleştirmeli, müşterinin işi, işyeri ve benzer konularda ilgili önerilerde bulunmalıdır. Çalışanların seçiminde ve faaliyetlerinin sürdürülmesinde de aynı dikkat gösterilmelidir. Çalışanların iş aidiyetinin oluşturulması, hizmet içi eğitim verilerek bilgi seviyelerinin arttırılması ve özellikle müşterilerle iletişim konusundaki eksikliklerin giderilmesi gerekmektedir

Muhasebe meslek mensuplarının çalışma ortamı ve teknolojik olanaklar açısından müşterilerin memnun olduğu istatistikî sonuçlardan anlaşılmaktadır.

Yapılan çalışmada ayrıca, müşteri memnuniyetinin ağızdan ağıza iletişimi olumlu yönde etkilediği tespit edilmiştir. Sonuç olarak, muhasebe meslek mensuplarının müşterilerine sunduğu hizmetlerin kalitesinin müşteri memnuniyetini doğrudan etkilediği ve müşteri memnuniyetinin de ağızdan ağıza iletişimi pozitif yönde etkilediği saptanmıştır. Memnun olan müşteriler çevreleri ile daha fazla işletme hakkında olumlu tavsiyelerde bulunur. Reklam ve benzeri pazarlama faaliyetlerinin yasak olduğu muhasebecilik alanında bu tür olumlu referansların olması firmaya çok büyük bir değer katacaktır.

$\mathrm{Bu}$ çalışma, muhasebe meslek mensuplarının hizmet kalitesinin müşteri memnuniyetine, memnuniyetin ağızdan ağıza iletişime etkisini ele almıştır. Muhasebe meslek mensuplarının sunduğu hizmet kalitesinin ölçümünde SERVQUAL ölçeği kullanılmıştır. Bu bağlamda hizmet kalitesine dair algılar kadar beklentilerin de ölçülmesinde fayda bulunmaktadır. Gelecek araştırmaların meslek mensuplarının hizmet kalitesi ölçümünde bu konunun dikkate alınmasının yanısıra SERVQUAL dışındaki farklı ölçekleri kullanması konuyu daha geliştirecektir. 


\section{Kaynakça}

Ağa, M., \& Şafaklı, O. V. (2007). An empirical investigation of service quality and customer satisfaction in professional accounting firms: evidence from North Cyprus. Problems And Perspectives In Management, 5(3), 84-98.

Akçi, Y., \& Kılınç, K. (2015). İşletme yöneticilerinin algıları açısından ağızdan ağıza iletişimin muhasebe meslek mensuplarının müşteri portföyüne etkisinin incelenmesi (Malatya örneği). Elektronik Sosyal Bilimler Dergisi, 14(55), 268-290.

Albez, A., \& Bilici, N. (2012). Meslek yüksekokulları muhasebe öğrencilerinin mesleğe bakışları: Atatürk Üniversitesi'nde bir araştırma. Atatürk Üniversitesi Sosyal Bilimler Enstitüsü Dergisi, 16(3), 383-398.

Arlı, E. (2012). Yat limanı işletmeciliğinde algılanan hizmet kalitesi faktörlerinin tekrar tercih etme niyeti, tavsiye etme niyeti ve genel memnuniyet düzeyi üzerindeki etkisi. Anatolia: Turizm Araştırmaları Dergisi, 23(1), 19-32.

Armstrong, R., \& Smith, M. (1996). Marketing cues and perceptions of service quality in the selection of accounting firms. Journal of Customer Service in Marketing \& Management, 2(2), 37-59.

Avcılar, M. Y. (2005). Kişisel etki kaynakları ve ağızdan ağıza iletişim ağı. Atatürk Üniversitesi İktisadi ve İdari Bilimler Dergisi, 19(2), 333-347.

Balaji, M. S., Khong, K. W., \& Chong, A. Y. L. (2016). Determinants of negative word-ofmouth communication using social networking sites. Information $\mathcal{E}$ Management, 1-43.

Banar, K., \& Ekergil, V. (2010). Muhasebe meslek mensuplarının hizmet kalitesi: sunulan hizmetlerin kalitesi ile müşteri memnuniyeti ilişkisi Eskişehir uygulaması. Anadolu Üniversitesi Sosyal Bilimler Dergisi, 10(1), 39-60.

Bayuk, M. N., \& Küçük, F. (2007). Müşteri tatmini ve müşteri sadakat ilişkisi. Marmara Üniversitesi İktisadi ve İdari Bilimler Fakültesi Dergisi, 22(1), 285-297.

Belanche, D., Casalo, L. V., \& Flavian, C.(2010). Providing online public services successfully: the role of confirmation of citizens' expectations. International Review on Public and Nonprofit Marketing, 7(2), 167-184.

Bojanic, D. C. (1991). Quality measurement in professional services firms. Journal of Professional Services Marketing, 7(2), 27-36.

Brown, J. J., \& Reingen, P. H. (1987). Social ties and word-of-mouth referral behavior. Journal of Consumer Research, 14(3), 350-362.

Brown, J., Broderick, A. J. \& Lee, N. (2007). Word of mouth communication within online communities: conceptualizing the online social network. Journal of Interactive Marketing, 21(3), 2-20.

Bulgan, U., \& Gürdal, G.(2005). Hizmet kalitesi ölçülebilir mi?, ÜNAK'05 Bilgi hizmetlerinin organizasyonu ve pazarlanması. 22 - 24 Eylül 2005 Kadir Has Üniversitesi, İstanbul, 240259.

Buttle, F. A. (1998). Word of mouth: understanding and managing referral marketing. Journal of Strategic Marketing, 6(3), 241-254. 
Chaniotakis, I. E. \& Lymperopoulos, C. (2009). Service quality effect on satisfaction and word of mouth in the health care industry. Managing Service Quality: An International Journal, 19(2), 229-242.

Chen, Y. H. (2011). The service quality and consumer behaviour analysis in Taiwan. ProcediaSocial and Behavioral Sciences, (25), 16-24.

Çelik, M. (2012). Müşteri memnuniyeti ve hizmet kalitesi üzerine Adryaman üniversitesi Yemekhanesi'nde bir uygulama. Adryaman Üniversitesi Sosyal Bilimler Enstitüsü Dergisi, (10), 29-54.

Derbaix, C., \& Vanhamme, J. (2003). Inducing word-of-mouth by eliciting surprise-a pilot investigation. Journal of Economic Psychology, 24(1), 99-116.

Devebakan, N., \& Aksaraylı, M. (2003). Sağlık işletmelerinde algılanan hizmet kalitesinin ölçümünde servqual skorlarının kullanımı ve özel Altınordu hastanesi uygulaması. Dokuz Eylül Üniversitesi Sosyal Bilimler Enstitüsü Dergisi, 5(1), 38-54.

Devebakan, N., Koçdor, H., Musal, B., \& Güner, G. (2003). Dokuz Eylül Üniversitesi sağlık bilimleri enstitüsünde lisansüstü eğitim kalitesinin arttırılması kapsamında öğrencilerin eğitime ilişkin görüşlerinin değerlendirilmesi. Dokuz Eylül Üniversitesi Sosyal Bilimler Enstitüsü Dergisi, 5(2), 30-44.

Edison, S. W., \& Geissler, G. L. (2011). An investigation of negative word-of-mouth communication among market mavens. Journal of Behavioral Studies İn Business, (3), 1-12.

Eleren, A., \& Kılıç, B. (2007). Turizm sektöründe servqual analizi ile hizmet kalitesinin ölçülmesi ve bir termal otelde uygulama. Afyon Kocatepe Üniversitesi İktisadi ve İdari Bilimler Fakültesi Dergisi, 9(1), 235-263.

Emir, O., Kılıç, G., \& Pelit, E. (2010). Üç yıldızlı otel işletmelerinde müşteri memnuniyeti üzerine bir araştırma. Süleyman Demirel Üniversitesi İktisadi ve İdari Bilimler Fakültesi Dergisi, 15(3), 291-310.

Ennew, C. T., Banerjee, A. K., \& Li, D. (2000). Managing word of mouth communication: empirical evidence from India. International Journal of Bank Marketing, 18(2), 75-83.

Erol, M. (2007). Muhasebe meslek elemanlarının sundukları hizmetlerin mükellefleri tatmin eden özelliklerini belirlemeye yönelik ampirik bir çalışma. Selçuk Üniversitesi Karaman İktisadi ve İdari Bilimler Fakültesi Dergisi, (12), 244-252.

Ersöz, S., Pınarbaşı, M., Türker, A. K., \& Yüzükırmızı, M. (2009). Hizmet kalitesinin servqual metodu ile ölçümü ve sonuçların yapısal eşitlik modelleri ile analizi: öğretmen evi uygulamasi. Int.J.Eng.Research \& Development, 1(1), 19-27.

Ertuğrul, İ., \& Özdemir, S. (2014). Muhasebe dersi alan ön lisans ve lisans öğrencilerinin derse yönelik tutumlarının tespiti: Ege Bölgesi'nde bir uygulama. Niğgle Üniversitesi İktisadi ve İdari Bilimler Fakültesi Dergisi, 7(1), 204-214.

Eru, O., \& Köroğlu, Ç. (2015). Kulaktan kulağa pazarlamanın mali müşavir-muhasebeci seçimine etkisi. International Journal of Social Sciences and Education Research, 1(4), 12631277. 
Ferguson, R. J., Paulin, M., \& Leiriao, E. (2007). Loyalty and positive word-of-mouth: patients and hospital personnel as advocates of a customer-centric health care organization. Health Marketing Quarterly, 23(3), 59-77.

Freeman, K. D., \& Dart, J. (1993). Measuring the perceived quality of professional business services. Journal of Professional Services Marketing, 9(1), 27-47.

Ghobadian, A., Speller, S., \& Jones, M. (1994). Service quality: concepts and models. International Journal of Quality \& Reliability Management, 11(9), 43-66.

Güney, S., \& Dizman, Ş. (2015). Muhasebe meslek mensuplarının işletmelerin beklentilerini karşılama düzeyi-Erzincan ili uygulaması. Atatürk Üniversitesi Sosyal Bilimler Enstitüsü Dergisi, 19(3), 315-336.

Ismail, I., Haron, H., Ibrahim, D. N., \& Isa, S. M.(2006). Service quality, client satisfaction and loyalty towards audit firms: perceptions of Malaysian public listed companies. Managerial Auditing Journal, 21(7), 738-756.

İlter, B. (2009). E-perakendecilikde e-hizmet kalitesi, müşteri memnuniyeti ve müşteri sadakati ilişkisi: işletme fakültesi öğrencileri üzerine bir araştırma. Dokuz Eylül Üniversitesi İşletme Fakültesi Dergisi, 10(1), 97-117.

Kalpaklığlu, N. Ü. (2015). Bir pazarlama iletişimi unsuru olarak e-wom'un turizm ürünleri tercihine etkisi. Maltepe Üniversitesi İletişim Fakültesi Dergisi, 2(1), 66-90.

Kaya, Y., \& Özdemir, S. (2014). Muhasebe meslek mensuplarının sundukları hizmetin müşteri tarafından ilişkisel pazarlama anlayışı doğrultusunda değerlendirilmesine yönelik ampirik bir çalışma. İşletme Araştırmaları Dergisi, 6(4), 157-171.

Kesik, F., \& Balcı, E. (2016). AB projelerinin katkılarını değerlendirme ölçeği: geçerlik ve güvenirlik çalışması. Kastamonu Ĕ̈itim Dergisi, 24(4), 1621-1640.

Kılıç, İ., \& Pelit, E. (2004). Yerli turistlerin memnuniyet düzeyleri üzerine bir araştırma. Anatolia: Turizm Araştırmaları Dergisi, 14(2), 113-124.

Kim, M. K., Park, M. C., \& Jeong, D. H. (2004). The effects of customer satisfaction and switching barrier on customer loyalty in korean mobile telecommunication services. Telecommunications Policy, 28(2), 145-159.

Koç, F., Şahin, N. K., \& Özbek, V. (2014). Hizmet hataları ve algılanan kalite arasındaki ilişki üzerinde değiştirme maliyetinin düzenleyici (moderator) etkisi: küçük işletmeler ve hizmet satın aldıkları muhasebecilere yönelik bir uygulama. Pazarlama Araştırmaları Dergisi, (14), 21-46.

Koçoğlu, C. M., \& Aksoy, R. (2012). Hizmet kalitesinin servperf yöntemi ile ölçülmesi: otobüs işletmeleri üzerinde bir uygulama. Akademik Bakış Dergisi, ( 29), 1-25.

Laczniak, R. N., Decarlo, T. E., \& Ramaswami, S. N. (2001). Consumers' responses to negative word-of-mouth communication: an attribution theory perspective. Journal of Consumer Psychology, 11(1), 57-73.

Ladhari, R.(2009). A review of twenty years of servqual research. International Journal of Quality and Service Sciences, 1(2), 172-198. 
Lassar, W. M., Manolis, C., \& Winsor, R. D. (2000). Service quality perspectives and satisfaction in private banking. Journal of Services Marketing, 14(3), 244-271.

Marangoz, M. (2007). Ağızdan ağıza iletişimin müşterilerin satın alma davranışlarına etkileri: cep telefonu pazarına yönelik bir araştırma. Çukurova Üniversitesi Sosyal Bilimler Enstitüsü Dergisi, 16(2), 395-412.

Öz, M., \& Uyar, E. (2014). Sağlık hizmetleri pazarlamasında algılanan hizmet kalitesi ve müşteri memnuniyeti üzerinde ağızdan ağıza pazarlamanın etkisini belirlemeye yönelik bir araştırma. Karamanoğlu Mehmetbey Üniversitesi Sosyal ve Ekonomik Araştırmalar Dergisi, 16(26), 123-132.

Özer, Ö., \& Günaydın, Y. (2010). Otel işletmelerinde müşteri memnuniyeti ve müşteri sadakati ilişkisi: dört yıldızlı otel işletmelerinde bir uygulama. Dokuz Eylül Üniversitesi İsletme Fakültesi Dergisi, 11(2), 127-154.

Özgüven, N. (2008). Hizmet pazarlamasında müşteri memnuniyeti ve ulaştırma sektörü üzerinde bir uygulama. Ege Akademik Bakış, 8(2), 651-682.

Parasuraman, A., Zeithaml, V. A., \& Berry, L. L. (1985). A conceptual model of service quality and its implications for future research. The Journal of Marketing, 49(4), 41-50.

Pinho, J. C., Macedo, I. M., \& Monteiro, A. P. (2007). The impact of online servqual dimensions on certified accountant satisfaction: the case of taxation services. Euromed Journal of Business, 2(2), 154-172.

Reeves, C. A., \& Bednar, D. A. (1994). Defining quality: alternatives and implications. The Academy of Management Review, 19(3), 419-445.

Saxby, C. L., Ehlen, C. R., \& Koski, T. R. (2004). Service quality in accounting firms: the relationship of service quality to client satisfaction and firm/client conflict. Journal of Business \& Economics Research, 2(11), 75-85.

Sweeney, J. C., Soutar, G. N., \& Mazzarol, T. (2008). Factors influencing word of mouth effectiveness: receiver perspectives. European Journal of Marketing, 42(3/4), 344-364.

Taşlıyan, M. (2007). Turizm ve seyahat sektöründe çalışanların iş tatmini ile müşterilerin memnuniyeti arasındaki ilişki: Kahramanmaraş'ta bir alan çalışması. Karamanoğlu Mehmetbey Üniversitesi Sosyal ve Ekonomik Araştırmalar Dergisi, (12), 185-195.

Taşoğlu, N. P.(2009). Pazarlama iletişimi (bütünleşik bir yaklaşım), 1. Baskı, Detay Yayıncılık: Ankara.

Taysı, K., \& Canbaz, S. (2017). Mükelleflerin muhasebecilere yönelik algılanan hizmet kalitesi ile müşteri memnuniyeti ilişkisi üzerine bir araştırma: Kırklareli örneği. International Congress on Politic, Economic and Social Studies, 9-11 November, Ankara Yıldırım Beyazit University-Ankara.

Tikici, M., \& Türk, M. (2003). İnsan odaklı yönetim ve müşteri memnuniyeti: Malatya ilinde bir uygulama. Süleyman Demirel Üniversitesi İktisadi ve İdari Bilimler Fakültesi Dergisi, 8(3), 27-48.

Türk, Z. (2009). Denetim firmalarının sunduğu hizmet kalitesi müşteri tatmini ve sadakati: servperf ölçeği. Çukurova Üniversitesi Sosyal Bilimler Enstitüsü Dergisi, 18(1), 399-416. 
Türker, G. Ö. (2014). Tüketici satın alma karar sürecinde ağızdan ağıza iletişimin rolü ve aai'nin etkinlik düzeyini belirleyen faktörlerin incelenmesi. Balıkesir Üniversitesi Sosyal Bilimler Enstitüsü Dergisi, 17(32), 151-177.

Tütüncü, Ö., \& Doğan, Ö. İ. (2003). Müşteri tatmini kapsamında öğrenci memnuniyetinin ölçülmesi ve dokuz eylül üniversitesi sosyal bilimler enstitüsü uygulaması. Dokuz Eylül Üniversitesi Sosyal Bilimler Enstitüsü Dergisi, 5(4), 130-151.

Ueltschy, L. C., Laroche, M., Eggert, A., \& Bindl, U. (2007). Service quality and satisfaction: an international comparison of professional services perceptions. Journal of Services Marketing, 21(6), 410-423.

Usta, R., \& Memiş, S. (2009). Hizmet kalitesi ve marka bağlılığ1 arasındaki ilişki üzerine müşteri tatmininin aracılık etkisi. Atatürk Üniversitesi İktisadi ve İdari Bilimler Dergisi, 23(4), 87-108.

Ustaahmetoğlu, E,. Aygün, D. \& Savcı, M. (2013). Muhasebe bürolarında sunulan hizmetin kalitesinin müşteriler tarafindan değerlendirilmesine yönelik bir uygulama. Uluslararası Yönetim İktisat ve Işletme Dergisi, 9 (18), 239-254.

Uzun, H. (2015). Servqual yöntemi ile özelleştirme algısına yönelik bir alan araştırması. Bankacılık ve Finansal Araştırmalar Dergisi, (2), 1-19.

Wang, R., Lin, Y. H., \& Tseng, M. L. (2011). Evaluation of customer perceptions on airline service quality in uncertainty. Procedia-Social and Behavioral Sciences, (25), 419-437.

Woodside, A. G., \& Delozier, M. W. (1976). Effects of word of mouth advertising on consumer risk taking. Journal of Advertising, 5(4), 12-19.

Yayla, H. E., \& Cengiz, E. (2006). Muhasebe bürolarında algılanan hizmet kalitesi ve mükelleflerin tatmin düzeylerine yönelik yapısal bir model önerisi II. Muhasebe ve Finansman Dergisi, (31), 175-184.

Yükselen, C. (2013). Pazarlama müşterinizle iletişiminizi güçlendirin, İSMMMO Yayınları 155: İstanbul. 